\title{
Techno-Economic Feasibility of Zoomlion Combine Harvester in Haor Areas of Bangladesh
}

\author{
A. K. M. Saiful Islam¹, Md. Ashraful Alam1, Muhammad Ashik-E-Rabbani², Md. Samiul Bashir², \\ Md. Mizanur Rahman ${ }^{*}$
}

${ }^{1}$ Bangladesh Rice Research Institute, Dhaka, Bangladesh

${ }^{2}$ Bangladesh Agricultural University, Mymensingh, Bangladesh

Email: *engr.mizanbau@gmail.com

How to cite this paper: Islam, A.K.M.S., Alam, Md.A., Ashik-E-Rabbani, M., Bashir, Md.S. and Rahman, Md.M. (2020) TechnoEconomic Feasibility of Zoomlion Combine Harvester in Haor Areas of Bangladesh. Agricultural Sciences, 11, 1170-1185. https://doi.org/10.4236/as.2020.1112077

Received: October 24, 2020

Accepted: December 18, 2020

Published: December 21, 2020

Copyright $\odot 2020$ by author(s) and Scientific Research Publishing Inc. This work is licensed under the Creative Commons Attribution International License (CC BY 4.0).

http://creativecommons.org/licenses/by/4.0/

\begin{abstract}
Haor represents the food basket of Bangladesh and rice is the only crop grown once a year. Harvesting of rice is labor-intensive works and required migrated labor to complete the harvesting works. Mechanical intervention of rice harvesting is urgently needed to increase the productivity. The proper knowledge of economic valuation and operational necessities needs to use of combine harvesters. Research objective was selected to test the technical and economic analysis of Zoomlion rice combine harvester (which is originally developed in China) in Maisherkandi, Mithamain Upazila under Kishoregonj district. The above-mentioned areas are representing haor areas of Bangladesh. Based on the straight-line method, fixed cost items which are machine purchase price, shelter, tax, and insurance were calculated. During the operation of the combine harvester variable cost items such as maintenance and repair, fuel, oil, drivers and guidance were collected. The breakeven point was calculated in terms of the hectares that must be harvested yearly to cover fixed annual costs; and the payback period. Harvesting speed ranged from $1.23-3.20 \mathrm{~km} \cdot \mathrm{hr}^{-1}$. The field capacity of harvester was obtained $0.15 \mathrm{ha} \cdot \mathrm{hr}^{-1}$ and consumed fuel of up to $32 \mathrm{~L} \cdot \mathrm{ha}^{-1}$. Field sizes of less than $800 \mathrm{~m}^{2}$ should be avoided for the Zoomlion combine harvester to operate the harvester machine in an efficient manner. The combine produced grains loss ranging from $1.60 \%-1.91 \%$. At an initial cost of Tk 2,000,000, owning the combine harvester becomes profitable after 20 ha of paddy field harvested at a harvesting capacity of $0.15 \mathrm{ha} \cdot \mathrm{hr}^{-1}$. Vibration and noise were observed in tolerable limit of the operator. The operator felt comfort to operate the machine. This machine is capable to operate in the muddy field having a water height of $4-8 \mathrm{~cm}$. Workability of the combine harvesters depended on soil, weather, crop condition, land size
\end{abstract}


and shape. The combine harvester was able to develop sufficient traction in soft soil during harvesting period in haor area. Zoomlion harvester is a cost-effective and time-saving machine but the initial costs are higher.

\section{Keywords}

Forward Speed, Plot Length, Field Size, Field Capacity, Annual Use, Break-Even Area

\section{Introduction}

Proper time of harvesting is now the best agricultural practice to sustain and increase the production, confirming the quality value of rice. Harvesting operation is one of the major activities in crop prevailed in haor areas. The labor force is now shifting rural areas to cities causes of rapid urbanization which creates the deficiency of labor during the rice harvesting season. However, the condition of increasing productivity cannot be satisfied attributable to the shortage of manpower at that particular harvesting time. At the same time, since 1976, land availability for cultivation in Bangladesh has dropped by 68,760 ha.year ${ }^{-1}$ (0.73 percent) [1]. The alternative way to meet the grain requirement of the increasing population is to increase production with the help of mechanization. In harvesting of rice, machines are already introduced in a small scale in Bangladesh. rice land whereas, seven people are required to harvest the same area in three days Field survey (2020) indicated that combine harvester takes one day to harvest one hectare of. Manual harvesting of rice is a laborious, time-consuming and costly operation that requires about $100-150$ persons to harvest 1 ha of paddy field [2]. Delayed harvesting incurred a huge loss of crops. Sometimes the whole area is inundated by flash floods. Delayed harvesting compelled the farmers to search for alternative arrangements. The only way to minimize the problem is to adopt harvesting machines to mitigate the labor shortage and avoid natural calamities. Mechanizing the harvesting operations will lead to greater productivity, resource conservation and decrease of crop production costs [3]. The use of rice combine harvester helps to reduce the cost of labor in the process of harvesting and threshing significantly [4] [5]; and to reduce the loss of productivity if harvested at the right time [6]. Rice combine harvesting is a higher net income and lower cost compared to labor harvesting. The paddy harvesting, overall cost savings were observed 52 percent in paddy harvesting by utilizing mini-combine harvester than manually harvesting [7]. Similarly, mini-combine harvester is labor savings and it was observed $65 \%$ over than manual harvesting. The harvesting loss (such as harvesting, threshing and cleaning) was found $1.24 \%$ in mini-combine and $6.36 \%$ in manual harvesting systems, respectively. However, mini-combine harvesters possess lower coverage than combines. The techno-economic performance of a combine harvester in the southern delta of Ban- 
gladesh and reported it as a successful entrepreneurial opportunity having a Benefit-Cost Ratio (BCR) of 1.55 [7]. Many factors govern the major operation of harvester, such as total area, machine availability, field to field distance, crop attributes, climate and soil quality, the enthusiasm and maintenance of the combined harvester, as well as financial aspects. A study was conducted in haor area of Mithimoin Upazila under Kishoreganj district and observed that larger sizes of plots are available which pre-requisite for efficient harvesting. The machine cost was categorized as fixed cost and variable costs [8] [9] [10]. Combine harvesters are getting popularity in haor areas to replace the conventional method of harvesting and threshing. In Bangladesh, combine harvesters are being available with subsidy from the government and variation in specification. It is appropriate to farmers in addition to its high purchasing price but there is an enormous potential for entrepreneurial venture dependent on combining harvester in haor areas. Combine harvester's technical and financial efficiency information is insufficient and differs from location to location, soil condition, and farmer's perception. Consequently, this research was conducted to determine the technical and economic feasibility of Zoomlion combine harvester in haor regions of Bangladesh.

\section{Methodology}

\subsection{Experimental Location and Period}

Figure 1 showing the research area of this study. The research was held throughout boro 2020 season at Maisherkandi, Mithamain upazila, underneath the district of Kishorganj. Rice crop was harvested by Zoomlion combine harvester

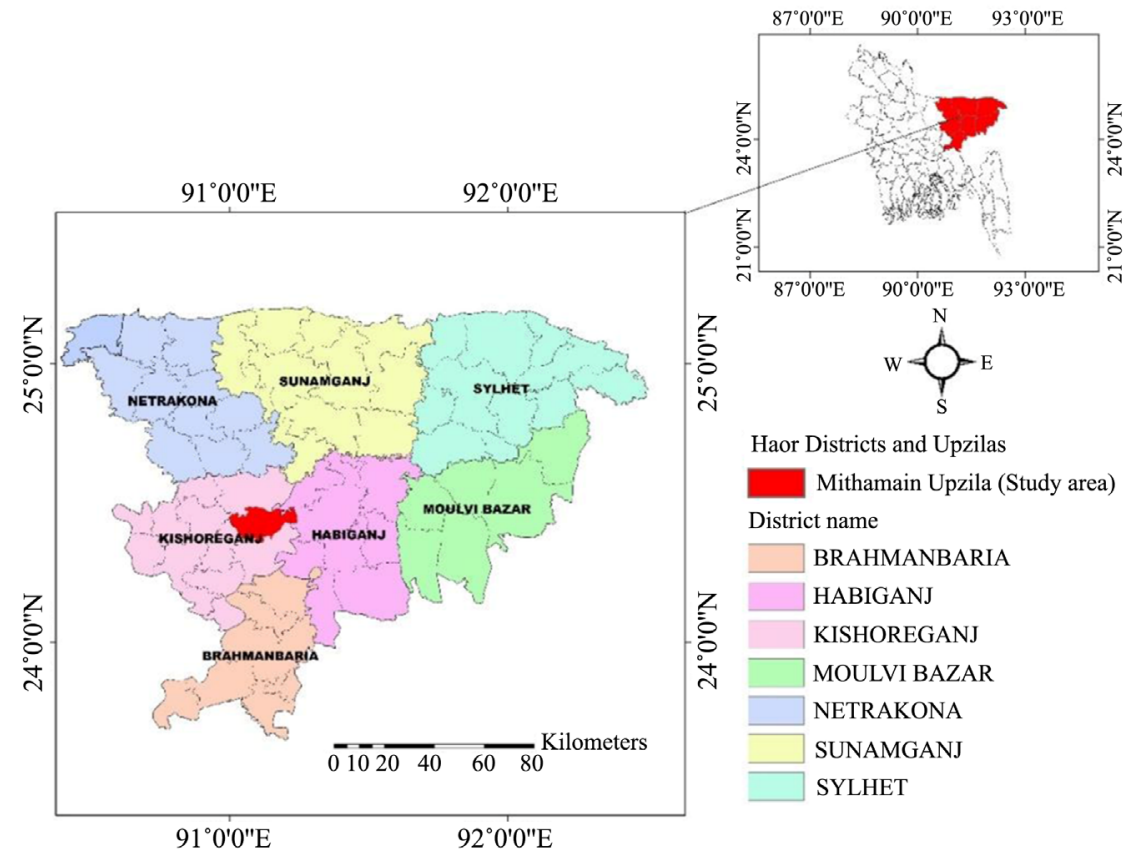

Figure 1. Location map of study area. 
from 16 March to 10 May. During the research period of this study, around 18 locations rice fields were selected. The most of the locations soil condition was sandy loam and data was gathering from selected 18 locations rice fields.

\subsection{Field Performance Parameters}

The criteria of field performance include machine running speed, theoretical field capability, actual field capacity and field efficiency, work per hour and consumption of fuel. The field efficiency is the ratio between effective field capacity and theoretical field capacity. The theoretical and effective field capacity was calculated below formulas [11] [12].

$$
\begin{gathered}
\text { Theoretical field capacity }\left(\mathrm{ha} \cdot \mathrm{h}^{-1}\right)=\frac{\text { Total area harvested }(\mathrm{ha})}{\text { Effective operation time }(\mathrm{h})} \\
\text { Effective field capacity }\left(\mathrm{ha} \cdot \mathrm{h}^{-1}\right)=\frac{\text { Total area harvested }(\mathrm{ha})}{\text { Total operation time }(\mathrm{h})} \\
\text { Field efficiency } \%=\frac{\text { Effective field capacity }}{\text { Theoretical field capacity }} \times 100
\end{gathered}
$$

The fuel consumption of the combine harvester was determined by differentiate the amount of fuel in tank before harvesting operation and amount of fuel in tank after harvesting time. Time parameters were measured utilizing automated stopwatch and the actual time (spending actual harvesting time), turning time (time of turning and reversing the machine without cutting rice plant), and idle time (operator resting and machine maintenance time). The total time was calculated in $\mathrm{h}$ /ha which was obtained by summarizing the whole-time parameters then divided it by the total harvesting area. To get the average time, total utilized time was summarizing and then it was divided by the number of total farms. The forwarding speed of Zoomlion combine harvester was obtained by taking total time needed to harvest each row and the amount of area harvest at that particular time.

\subsection{Technical Specifications of Combine Harvester}

Technical specification of Zoomlion model combine harvesters is given in Table 1.

\subsection{Operation Principle}

Field operation of Zoomlion combine harvester in haor areas is shown in Figure 2. Inlet operation of the combine started when the machine moves forward direction the separator separates the crop for harvesting, the reel picks up the standing or laying crops and moves them to the cutting device. The auger transmits the retracting fingers passing the crop to the inclination conveyor chain feeding the crop into the thresher. The cylinder and concave assembly play a crucial role in dividing most of the crop into seed, chaffers that fall directly onto the grain pan or a conveyor with in thresher. At this point, the cylinder 


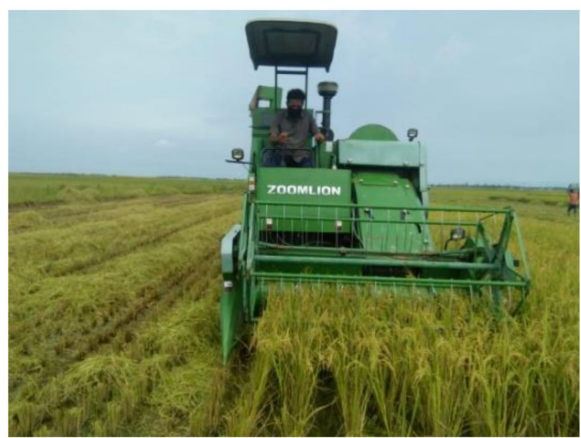

Inlet operation

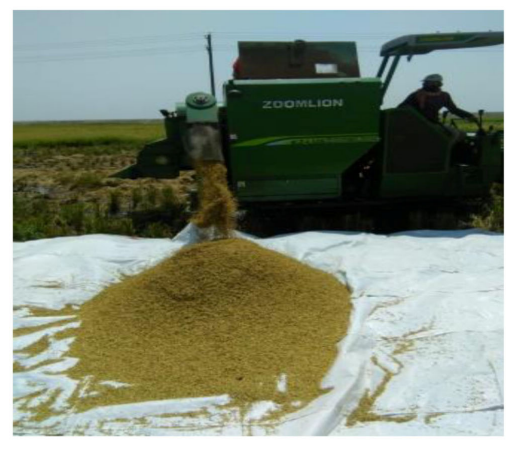

Outlet operation

Figure 2. Field operation of Zoomlion combine harvester in haor areas.

Table 1. Technical specifications of Zoomlion combine harvester.

\begin{tabular}{|c|c|}
\hline Parameters & \\
\hline Harvester Name & Zoomlion \\
\hline Number of Model & 4LZT-4.0ZD \\
\hline Origin & China \\
\hline Price & $2,000,000$ \\
\hline Max power & $67 \mathrm{~kW}$ \\
\hline Rated speed & 2400 \\
\hline Total weight & $3260 \mathrm{~kg}$ \\
\hline Tracking tire & Full track \\
\hline Minimum ground clearance, $\mathrm{mm}$ & 325 \\
\hline Type of fuel & Diesel \\
\hline Capacity of fuel tank (L) & 160 \\
\hline Cutting width (m) & 2.0 \\
\hline Feeding size $(\mathrm{kg} / \mathrm{s})$ & 4.0 \\
\hline Capacity of grain tank $\left(\mathrm{m}^{3}\right)$ & 1.4 \\
\hline Discharge of unloading & $\mathrm{kg} / \mathrm{s}$ \\
\hline Header auger & Spiral blade + Eccentric telescopic rod rack \\
\hline Facility of bagging & No \\
\hline $\begin{array}{l}\text { Capacity of grain cleaning } \\
\text { (depending on moisture level) }\end{array}$ & Good \\
\hline Man power & 1 or 2 Man \\
\hline
\end{tabular}

beater starts to strip the threshed material from cylinder and supports in further separation and directs the straw and remaining seed to the straw carrier. The straw carrier aggravates the material to remove any existing seed and un-threshed heads as the straw is moved backward from the machine to be discharged. A crop transfer conveyor gathers the material extracted from the straw and is delivered to the crop container at the front of the chaffer sieve. The combination of threshed grain with several chaffer and small debris drops from the concave 
sieve falls to an oscillating sieve and is clean by a fan and the oscillating sieve together. After cleaning, a horizontal auger and a lifting auger delivers the grain to the grain tank. The tailings are then transferred through the oscillating sieve to the rear outlet. The straw in the thresher is poured out off the field after threshing through the straw outlet. The threshed and clean grain is discharged by grain outlet pipe in the sack or grain tank at the sacking site.

\subsection{Field Data Collection}

Figure 3 showing the field data collection of Zoomlion combine harvester. A total of 18 fields data were collected according to plot size. The plot size of the field was measured with help of measuring tape. Each turning time and passing time was recorded using stopwatch. The events and time loss were calculated according to plot sizes.

\subsection{Grain Loss Assessment}

Before and after harvesting, grain fallen data in $1 \mathrm{~m}^{2}$ was collected in three places in each field. Moisture and weight of the grain were recorded and measured as a percentage of total yields in unit area.

\subsection{Valuation of Financial Possibility}

The costs were divided into two categories in separate harvesting segments (both mechanized and manual methods) which are fixed cost, and variable cost.

\subsection{Financial Investigation}

The combine harvester's operating costs were calculated using the equation below.

$$
A C=F C+V C
$$

where,

$$
\begin{aligned}
& A C=\text { Yearly operational cost }, \mathrm{Tk} \cdot \mathrm{yr}^{-1} \\
& F C=\text { Yearly fixed cost }, \mathrm{Tk} \cdot \mathrm{yr}^{-1}
\end{aligned}
$$

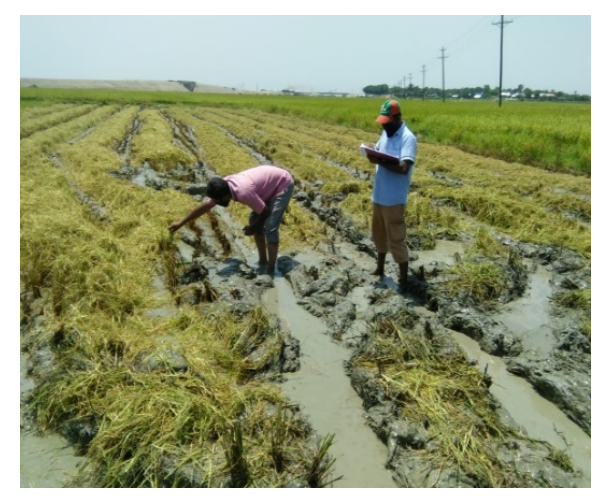

(a)

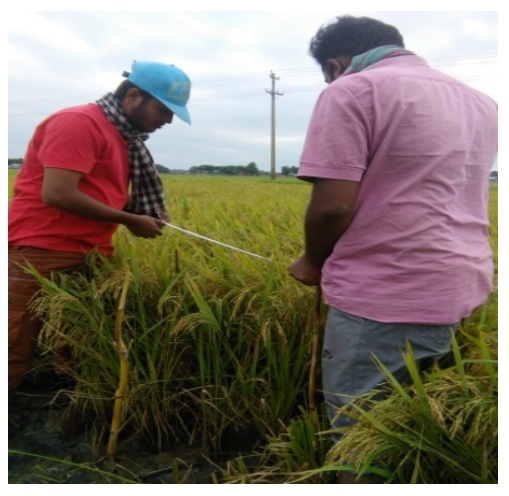

(b)

Figure 3. Turning event and time loss (a) data collection according to plot size (b). 
$V C=$ Variable cost, $\mathrm{Tk} \cdot \mathrm{yr}^{-1}$

\subsection{Fixed Cost $(F C)$}

It is self-determining use of machine and assessed on the basis of the method of capital consumption $(C C)$. A capital recovery factor $(C R F)$ has been employed to incorporate gross depreciation and interest adjustments into a sequence of compound interest equivalent annual payments. The capital recovery factor can be described as the sum of equivalent (or uniform) payments to be obtained for $n$ years, so that, if the rate of interest is the cumulative present value of many of these equal installments is currently equivalent to one taka. This payment is being used to calculate agricultural machinery capital use [13].

$$
\begin{gathered}
C C=(P-S) C R F+S \times i \\
C R F=\frac{i(i+1)^{n}}{(1+i)^{n}-1}
\end{gathered}
$$

where,

$C C=$ capital of consumption

$P=$ combine harvester's purchase price $(\mathrm{Tk})$

$S=$ salvage value $(\mathrm{Tk})$

$C R F=$ recovery factor of capital

$i=$ interest on investment (\%)

$n=$ machine life $(\mathrm{yr})$

\subsection{Variable Cost (VC)}

These variable costs are applied to combine harvester usage and assessed on the basis of the continuity formula [13].

$$
V C=\frac{A}{C}[(R \& M) \times P+L]
$$

where,

$$
\begin{aligned}
& A=\text { area coverage yearly (ha) } \\
& C=\text { effective field capacity }\left(\text { ha } \cdot \mathrm{hr}^{-1}\right) \\
& R \& M=\text { repair and maintenance cost }(\%) \\
& L=\text { labor wage }\left(\mathrm{Tk} \cdot \mathrm{hr}^{-1}\right)
\end{aligned}
$$

\subsection{Break-Even Analysis}

The break-even point $(B E P)$ is the stage where there is no benefit or loss. The farm enterprise's overall costs should be the same as total profits. Continuous investigation of farm machine operating costs is necessary. The fixed costs of the farm ought to be met by the profits: the greater the fixed costs, the longer it will take for the enterprise to hit break-even and turn a profit. Therefore, holding the fixed costs down to a minimum level is important. The equation below was used to estimate the machine's $B E P$. 


$$
B E P=\frac{F C}{C R-V C}
$$

where,

$$
\begin{aligned}
& B E P=\text { break-even point }\left(\mathrm{ha} \cdot \mathrm{yr}^{-1}\right) \\
& F C=\text { fixed cost of machine }\left(\mathrm{Tk} \cdot \mathrm{yr}^{-1}\right) \\
& V C=\text { variable cost of machine }\left(\mathrm{Tk} \cdot \mathrm{ha}^{-1}\right) \\
& C R=\text { rate of custom hire }\left(\mathrm{Tk} \cdot \mathrm{ha}^{-1}\right)
\end{aligned}
$$

\subsection{Calculation of Rental Charge}

The per unit area rent charge normally depends on the cost of the machine, useable fuel, labor cost, transportation costs, yearly use and benefit.

\subsection{Assumptions}

The rental charge of the combine harvester was calculated based on the following assumptions:

- The combine harvester's purchase price was taken as Tk 2,000,000.

- Government aid accounts for 70 percent of the machine price in haor region.

- The investment interest rate for banks is taken 12 percent.

- Rice harvester's repair and maintenance cost is taken as 5 percent of its purchase price.

- The combine harvester's life is taken to be 8 years.

- Take fuel price as Tk $70 \mathrm{~L}^{-1}$.

- Labor charge is taken as Tk $900 \mathrm{Day}^{-1}$.

- Manual harvesting and threshing costs were taken as Tk 16,500 ha ${ }^{-1}$.

\subsection{Farmers' Preference}

Comments on the performance of combine harvester were recorded from the users and operators throughout by structured questionnaire. The comments were validated through KII (Key Informant Interviews).

\subsection{Data Collection and Analysis}

We used MS-Excel 2013 software to analyze the data and then visualized the results in tabulated and graphical formation.

\section{Results and Discussion}

\subsection{Turning Events}

Figure 4 has shown that turning event decreases with increase the plot length. Combine harvester should be operated in plot length of more than $30 \mathrm{~m}$ to reduce turning events. In the current land tenure system, the rice fields are mostly fragmented due to changes in ownership. Farmers themselves also artificially fragmented the land for good water management in rice cultivation. Harvesting efficiency depended on the plot size and plot length [3]. He suggested the operator to operate the farm machine in lengthwise to reduce the turning events. 


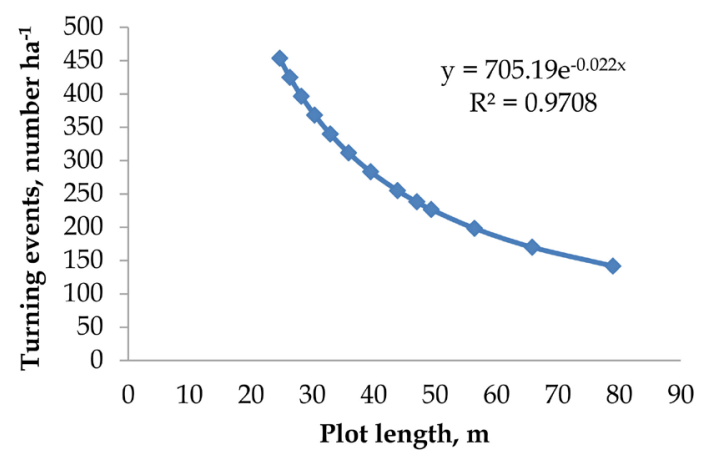

Figure 4. Turning events of Zoomlion combine harvester according to plot length.

\subsection{Time Loss in Turning}

Figure 5 shows the time loss in turning decreases with increase the plot size. Smaller sizes of plot required more turning events which increase the time loss turning. Plot areas should be selected more than $800 \mathrm{~m}^{2}$ to operate Zoomlion combine harvester having the cutting width of $2.0 \mathrm{~m}$ in full capacity as well as minimize the turning loss. The recommended plot should be more than $500 \mathrm{~m}^{2}$ to operate head feed combine harvester in an efficient manner.

\subsection{Harvesting Capacity of Combine Harvester with Respect to Land Size}

The combine harvester's harvest capability relied on the size of the field. Figure 6 shows the combine harvester field capability in reference to the land area. The harvesting capacity increased when the field size was increased. Combine harvester worked at full capacity for the larger sizes of land due to less turning events. The size of the land should be at least $800 \mathrm{~m}^{2}$ to operate the combine harvester having a cutting width of $2 \mathrm{~m}$ at full capacity. The benefit of large area makes to help the combine better field capacity. [13] studied the land sizes in haor areas and observed that most of the lands are bigger in size. Crop field should be selected based on the size of the land to get the highest field performance of combine harvester.

\subsection{Field Efficiency}

Figure 7 demonstrates the combine harvester's field productivity with regards to the land area size. Combine harvester field performance varied with land size. The field efficiency increases with the increase in land size. The highest field efficiency was observed the land sizes of more than $2000 \mathrm{~m}^{2}$. Field efficiency showed the lowest in the field sizes of $800 \mathrm{~m}^{2}$. Hence, field sizes of less than 800 $\mathrm{m}^{2}$ should be avoided for the Zoomlion combine harvester.

\subsection{Field Performance of Combine Harvesters in haor Area}

Table 2 shows the field capacity and field efficiency of combine harvester. The operating speed of the combine harvester is $1.23-3.20 \mathrm{~km} \cdot \mathrm{hr}{ }^{-1}$. [13] observed 


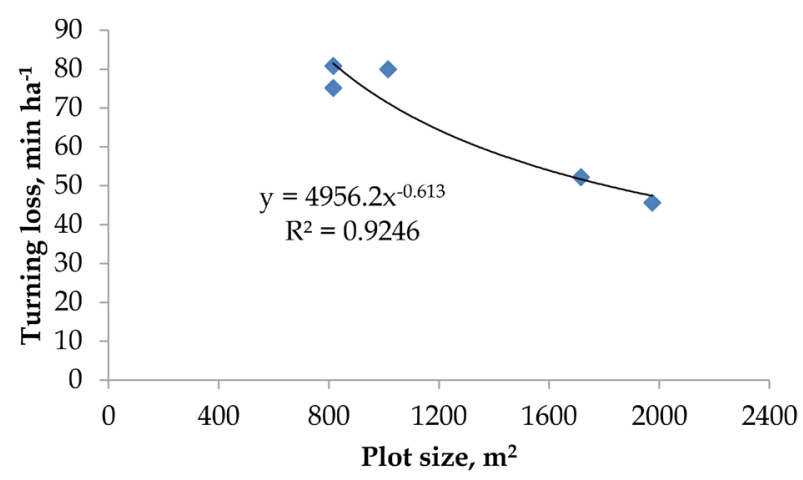

Figure 5. Time loss during turning operation of Zoomlion combine harvester according to plot size.

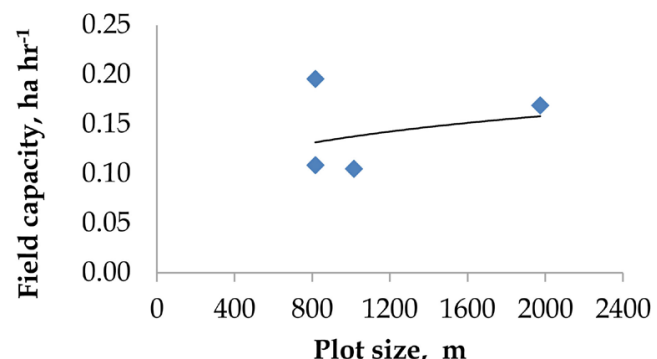

Figure 6. Field capacity of combine harvester with respect to land size.

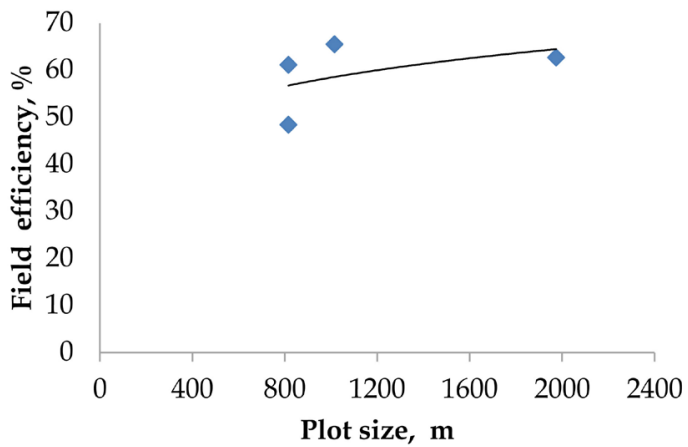

Figure 7. Field efficiency of combine harvester with respect to land size.

Table 2. Field performance of combine harvester.

\begin{tabular}{cc}
\hline Parameter & Value \\
\hline Speed, $\mathrm{km} \cdot \mathrm{hr}^{-1}$ & $2.43 \pm 0.67$ \\
Lengthwise speed, $\mathrm{km} \cdot \mathrm{hr}^{-1}$ & $2.95 \pm 0.88$ \\
Widthwise speed, $\mathrm{km} \cdot \mathrm{hr}^{-1}$ & $1.91 \pm 0.69$ \\
Theoretical field capacity, ha·hr ${ }^{-1}$ & $0.24 \pm 0.07$ \\
Actual field capacity, ha $\cdot \mathrm{hr}^{-1}$ & $0.15 \pm 0.04$ \\
Field efficiency, \% & $63 \pm 12$ \\
Fuel consumption, L.ha & 32 \\
Grain loss, \% & $1.6-1.9$
\end{tabular}


the operating speed of Sifang and small combine harvester was 1.60 and 0.79 $\mathrm{km} \cdot \mathrm{hr}^{-1}$. The variation of operating speed was due to high horsepower and good trafficability of combine harvester. Crawler size was also bigger to developing sufficient traction than those of combine harvesters. The operational speed of the traditional and medium sized combine harvester would be within the recommended operating speed of $3-6.5 \mathrm{~km} \cdot \mathrm{hr}^{-1}$ for combine harvesting performance with a self-propelled combine by [14]. The forward speed of combine harvester in lengthwise operation was higher than the widthwise operation. Widthwise operation reduced the 35\% speed than lengthwise operation. The theoretical and actual field capacity of Zoomlion combine harvester was 0.15 ha.hr ${ }^{-1}$. [14] considered 0.50 and $0.36 \mathrm{ha} \cdot \mathrm{hr}^{-1}$, respectively, to be theoretical and effective field capacities of whole-crop and head-feed combinations. [15] recorded that paddy harvest would have the largest time on the field $(1.54 \mathrm{~h})$ and the lowest field capability $\left(0.67 \mathrm{ha} \cdot \mathrm{hr}^{-1}\right)$ of all the activities supported by their study. Fuel consumption was found $32 \mathrm{~L} \cdot \mathrm{hr}^{-1}$. Fuel consumption varied depending on the field size, turning events, travelling distance, soil condition. Grain loss was observed as $1.6 \%-1.9 \%$ respectively.

\subsection{Time Distribution in Combine Harvester Operation}

Figure 8 shows that the combine harvester spent $45 \%$ of the total harvesting time of operation. During the study it was found that $17 \%$ of the total turning time was spent with combine harvester. The others $38 \%$ time was spent in combine repairing, idle, work stop due to rain. Sifang and small combine harvester spent $45 \%$ and $56 \%$ time spent for harvesting rice in haor areas. [15] stated that, by using traditional combine, $66 \%$ of the total harvesting time was used to conduct the actual harvesting activities while turning and reversing time constituted $13 \%$ of the total harvesting operation. Turning time of combine harvester is lost factor operation which need to proper plan to make the turn without slower or additional gesture to the line up to the next row. Some nonproductive activities (turning time, adjustment time, etc.) are unavoidable; the goal is to minimize the sum of these nonproductive activities, as they may total as much as $40 \%$. The time factor may be optimizing by using proper plan and supervision.

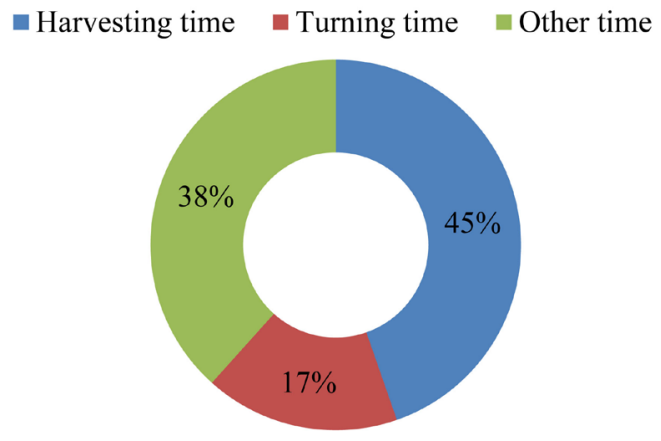

Figure 8. Time distribution in combine harvester operation. 


\subsection{Material Handling}

Materials handling is the overall man and machinery relationship in field and lab conditions. Materials handling including the combine harvester operation, feeding, cutting, threshing, cleaning, storage, protection, and material control.

\subsection{Repair and Maintenance}

Repair and maintenance rates are significant factor in assessing of a combine. The combine needed so little maintenance and repair mostly during entire harvest season.

\subsection{Operation Cost}

Variable cost i.e. operational cost of combine was characterized as labor's charge, cost of useable fuel and cost of repair (Figure 9). Operator's charge indicated the largest share followed by fuel cost. Daily repairing cost was observed in minimum level.

\subsection{Break-Even Area}

Figure 10 illustrates the break-even chart for mechanized methods using the mini combine harvester. The break-even area of mechanized harvesting using mini combine harvester would be 20 hectare of rice land.

- Operators Charge $\quad$ Fuel Cost $\square$ Repair Cost

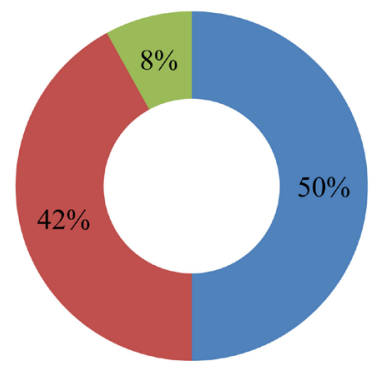

Figure 9. Operational cost distributions of Zoomlion combine harvester.

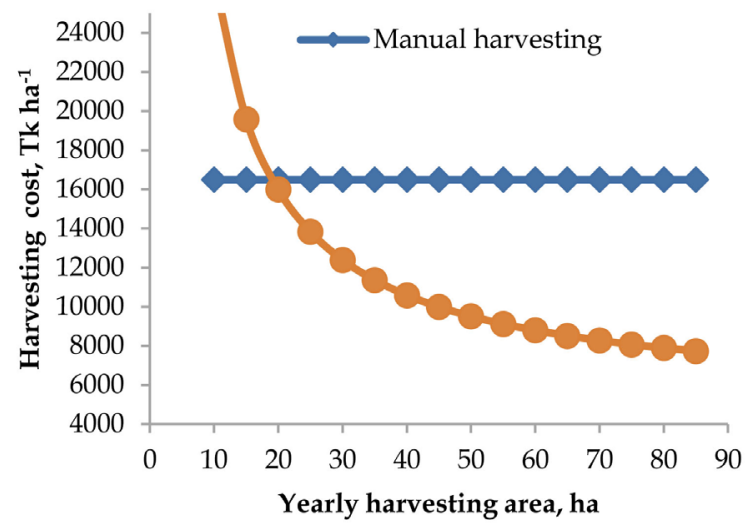

Figure 10. Break even area with respect to area coverage. 


\subsection{Operators' Experience}

The skill of the operator is very important to run the combine harvester efficiently. The machine has the ability to run faster. The adjustments of the combine harvester need to be made according to type and variety of crop, moisture content of crop (soft or dry), time of harvest, field, density of crop and crop conditions (lodged/unlodged), etc. Improper adjustments cause damage to grains or machine. Operator has to take instant decision on the adjustment of different parts. The machine should be operated in lengthwise to reduce the turning events. Adjacent field should be selected to reduce plot to plot movement time. Sudden turn is strictly prohibited.

\subsection{Machine Status during Operation}

Mechanical fault of the combine harvester during harvesting operation was summarized and presented in Table 3.

\subsection{Operators' Comments}

Operators' were asked to make comments on the following issues. The comments are summarized and given in Table 4.

\subsection{Farmers' Comments}

Farmers were asked to express comments on the following issues. The comments are summarized and given in Table 5.

\subsection{Overall Observation}

Overall observation on the crop and land condition was recorded and presented in Table 6.

Table 3. Machine status during operation.

\begin{tabular}{|c|c|}
\hline Parameters & Comments \\
\hline Header unit & Pentagon reel successfully gathered the crop. \\
\hline Cutting unit & $\begin{array}{l}\text { Cutter bar moves smoothly and successfully cut the crop. } \\
\text { Could not find uncut crop. }\end{array}$ \\
\hline Conveying unit & $\begin{array}{l}\text { Cut crop conveyed to the threshing drum by conveyer belt. It has the } \\
\text { ability to overcome the clogging tendency in the conveying unit. }\end{array}$ \\
\hline Threshing unit & Grains were separated from panicle successfully. \\
\hline Cleaning unit & $\begin{array}{l}\text { Blower is attached to the machine to clean the grain. } \\
\text { Cleaning was good. }\end{array}$ \\
\hline Storage unit & $\begin{array}{l}\text { Grains were stored in the tank and unloading operation } \\
\text { was after filling tank or at the end of the harvesting. }\end{array}$ \\
\hline $\begin{array}{l}\text { Power transmission } \\
\text { system }\end{array}$ & Gear changing mechanism is operator's friendly. \\
\hline Turning & Difficult to turn the harvester especially right turning. \\
\hline Vibration and noise & Vibration and noise are in tolerable limit of the operator. \\
\hline
\end{tabular}


Table 4. Operators' comments on the performance of combine harvester.

\begin{tabular}{|c|c|}
\hline Parameters & Comments \\
\hline Operation & $\begin{array}{l}\text { Operators' felt comfort to operate the harvester. Machine can be } \\
\text { operated at night also due to in-build good lighting arrangements. }\end{array}$ \\
\hline $\begin{array}{l}\text { Lowering and } \\
\text { uplifting in the field }\end{array}$ & There is a problem in uplifting on higher ground due to larger size. \\
\hline Unusual breakdown & Unusual breakdown was not observed during operation. \\
\hline Parts availability & $\begin{array}{l}\text { Parts are not available nearer to the rice field. The available machine } \\
\text { parts market situated long distance place from rice fields. The operator } \\
\text { has to maintain stock on most vulnerable parts to avoid loss time. }\end{array}$ \\
\hline Driving on the road & $\begin{array}{l}\text { The width of machine was } 2 \mathrm{~m} \text { and surrounded the whole road while } \\
\text { moving on the rural roads. However, turning in the road caused } \\
\text { crawler damage. }\end{array}$ \\
\hline Trouble & $\begin{array}{l}\text { It is almost trouble-free machine. Pre-cautions should be taken on the } \\
\text { proper repair and maintenance before operating in the field. }\end{array}$ \\
\hline Parameters & Comments \\
\hline Grain cleaning & $\begin{array}{l}\text { More than } 95 \% \text { cleaned grain was obtained. Every farmer satisfied } \\
\text { the grain cleaning. }\end{array}$ \\
\hline Grain damage & Farmers' did not find any significant amount of grain damage. \\
\hline $\begin{array}{l}\text { Status of straw } \\
\text { after harvesting }\end{array}$ & $\begin{array}{l}\text { Straws were chopped after harvesting. Every farmer opined that they } \\
\text { can keep straw for long time after getting from combine harvester. }\end{array}$ \\
\hline Grain collection & $\begin{array}{l}\text { Grans were collected in storage tank. Unloading operation was } \\
\text { done nearer to the field. }\end{array}$ \\
\hline Threshing loss & $\begin{array}{l}\text { Farmers find nominal unthreshed grain in the straw which is } \\
\text { acceptable by the farmers. }\end{array}$ \\
\hline Harvesting capacity & Harvesting capacity is very high. \\
\hline
\end{tabular}

Table 6. Overall observation on the crop and land condition.

\begin{tabular}{|c|c|}
\hline Parameters & Comments \\
\hline Land condition & Sandy soil. Land shapes are regular. Water splashes in the field \\
\hline Depth of mud & $4-9 \mathrm{~cm}$ \\
\hline Crop position & $10 \%$ crops inclined. Lodged crop was observed in some fields \\
\hline Crop density & Moderate to high density \\
\hline Crop height & $84-95(\mathrm{~cm})$ \\
\hline $\begin{array}{l}\text { Straw left in the } \\
\text { field after harvesting }\end{array}$ & $9-14(\mathrm{~cm})$ \\
\hline Overall comments & $\begin{array}{l}\text { According to farmers comments the Zoomlion combine } \\
\text { harvester performance was found satisfactory }\end{array}$ \\
\hline
\end{tabular}




\subsection{Drawbacks of Zoomlion Combine Harvester in haor Areas}

Larger harvesting machine like Zoomlion is not suitable in haor areas.

During the operation, wet paddy creates heat in grain tank.

Spare parts are not available in local markets.

* Repair and maintenance are not easy of this combine harvester due to its heavy weight.

\section{Conclusion}

Zoomlion combine harvester was found as a promising technology especially for haor areas due to its overall better performance. Optimizing the initial higher cost of Zoomlion combine harvester, it is an effective, cost and labor saving, and reduces time to harvest the rice during the rice harvesting season. Machines showed better performance in larger sizes of fields. Farmers will be able to harvest their crops within a very short time consequently avoid the natural calamities.

\section{Recommendation}

Combine harvesters should be evaluated across various agro-ecological zones under a diverse range of crop and soil conditions.

\section{Acknowledgements}

The author acknowledges the funding support of "Strengthening Farm Machinery Research Activity for Mechanized Rice Cultivation project, Bangladesh Rice Research Institute, Gazipur.

\section{Conflicts of Interest}

The authors declare no conflicts of interest regarding the publication of this paper.

\section{References}

[1] Hasan, M.K., Ali, M.R., Saha, C.K., Alam, M.M. and Haque, M.E. (2019) Combine Harvester: Impact on Paddy Production in Bangladesh. Journal of the Bangladesh Agricultural University, 17, 583-591. https://doi.org/10.3329/jbau.v17i4.44629

[2] Alizadeh, M.R. and Allameh, A. (2013) Evaluating Rice Losses in Various Harvesting Practices. International Research Journal of Applied and Basic Sciences, 4, 894-901.

[3] Islam AKMS (2020) Business Viability of Small Combine Harvester in Haor Areas. An Unpublished Report. Submitted to the Project Director, Strengthening Farm Machinery Research Activity for Mechanized Rice Cultivation Project, Bangladesh Rice Research Institute, Gazipur.

[4] Hossain, M.A., Hoque, M.A., Wohab, M.A., Miah, M.A.M. and Hassan, M.S. (2015) Technical and Economic Performance of Combined Harvester in Farmers' Field. Bangladesh Journal of Agricultural Research, 40, 291-304. https://doi.org/10.3329/bjar.v40i2.24569

[5] Poungchompu, S. and Chantanop, S. (2016) Economic Aspects of Rice Combine 
Harvesting Service for Farmer in Northeast Thailand. Asian Social Science, 12, 201-211. https://doi.org/10.5539/ass.v12n8p201

[6] Chinsuwan, W., Mongpraneet, S. and Panya, N. (1997) Optimum Harvest Period for Hommali Rice Using Combine Harvester. Warasan Wichai Mo-Kho, 2, 54-63.

[7] Kepner, R.A. and Bainer, R. (1982) Principles of Farm Machinery. 3rd Edition, AVI Publishing Company, Westport.

[8] Hunt, D. (2001) Farm Power and Machinery Management. 10th Edition, Iowa State University Digital Press, Iowa.

[9] William, L. (2005) Farm Machinery Economic Cost Estimates. Extension Farm Management Specialist. Nebraska University, Lincoln.

[10] ASAE (2005) Uniform Terminology for Agricultural Machinery Management. American Society of Agricultural and Biological Engineers, St. Joseph, Michigan. https://www.asabe.org/.

[11] Amponsah, S.K., Addo, A., Dzisi, K.A., Moreira, J. and Ndindeng, S.A. (2017) Performance Evaluation and Field Characterization of the Sifang Mini Rice Combine Harvester. Applied Engineering in Agriculture, 33, 479-489. https://doi.org/10.13031/aea.11876

[12] Hunt (1995) Farm Power and Machinery Management. 9th Edition, Iowa State University Press, Iowa, $363 \mathrm{p}$

[13] Islam, A., Rahman, M.A., Rahman, A., Islam, M.T. and Rahman, M.I. (2016) Techno-Economic Performance of 4-Row Self-Propelled Mechanical Rice Transplanter at Farmers Field in Bangladesh. Progressive Agriculture, 27, 369-382. https://doi.org/10.3329/pa.v27i3.30834

[14] ASAE (2009) Agricultural Machinery Management Data. American Society of Agricultural and Biological Engineers, 85, 350-357.

[15] Muazu, A., Yahya, A., Ishak, W.I.W. and Khairunniza-Bejo, S. (2014) Machinery Utilization and Production Cost of Wetland, Direct Seeding Paddy Cultivation in Malaysia. Agriculture and Agricultural Science Procedia, 2, 361-369. https://doi.org/10.1016/j.aaspro.2014.11.050 